\title{
PEMBERDAYAAN PEKERJA PEREMPUAN \\ SEBAGAI UPAYA PENINGKATAN EKONOMI KELUARGA \\ DALAM PERSPEKTIF HUKUM ISLAM
}

Juju Jumena, Djohar Arifin dan Halimatu Sa'diyah

Fakultas Syariah dan Ekonomi Islam

Institut Agama Islam Negeri Syekh Nurjati Cirebon

email: jumena72@yahoo.com,ibnu_maksum03@yahoo.com dan imaneng930@gmail.com

\begin{abstract}
In Islamic law women are allowed to work for a living, because sometimes parents or husbands can not afford and bear the cost of their lives. As a result encourage women to work to earn additional income to meet family needs. The existence of educational background factors are minimal, making the woman in the end looking for work in accordance with the ability he has. The type of research used is library research and survey research, with qualitative approach. Based on research in terms of empowerment of women workers as an effort to improve the family economy, in accordance with the views of Islamic law. Most of them have the support of family and the environment, while maintaining ethics and morale in their work. The empowerment of women workers has a positive impact that family income increases, although the increase is different.
\end{abstract}

Keywords: Empowerment of Women, Family Economics and Islamic Law.

\begin{abstract}
Abstrak
Dalam hukum Islam perempuan diperbolehkan untuk bekerja mencari nafkah, karena terkadang orangtua atau suami tidak mampu mencukupi dan menanggung biaya hidup mereka. Alhasil mendorong perempuan bekerja mencari penghasilan tambahan untuk memenuhi kebutuhan keluarga. Adanya faktor latar pendidikan yang minim, membuat perempuan tersebut pada akhirnya mencari pekerjaan sesuai dengan kemampuan yang dimilikinya. Jenis penelitian yang digunakan adalah penelitian kepustakaan (library research) dan penelitian survey, dengan pendekatan deksriptif kualitataif. Berdasarkan penelitian dalam hal pemberdayaan pekerja perempuan sebagai upaya meningkatkan perekonomian keluarga, sesuai dengan pandangan hukum Islam. Sebagian besar dari mereka mendapat dukungan dari keluarga dan lingkungan, tetap menjaga etika dan moral dalam pekerjaan mereka. Pemberdayaan pekerja perempuan memiliki dampak positif yakni penghasilan keluarga meningkat, walaupun peningkatannya berbeda-beda.
\end{abstract}

Kata Kunci: Pemberdayaan Perempuan, Ekonomi Keluarga dan Hukum Islam. 


\section{PENDAHULUAN}

Dalam sebuah ayat yang menjelaskan tentang kedudukan perempuan, seringkali di jadikan alasan ketidakbolehan perempuan untuk memiliki peran selain peran domestik di dalam rumah. Padahal Islam tidak bermaksud menetapkan suatu hukum yang menguntungkan bagi satu pihak dan merugiakan pihak lain, melainkan memberi kemaslahatan bagi semua pihak, kepada kaum laki-laki dan kaum perempuan. Firman Allah SWT:
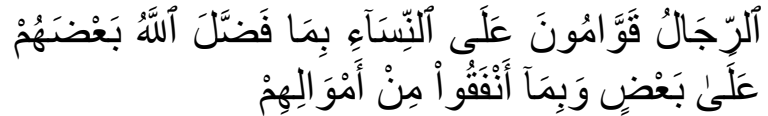

Artinya: "Kaum laki-laki itu adalah pemimpin bagi kaum wanita, oleh karena Allah telah melebihkan sebahagian mereka (laki-laki) atas sebahagian yang lain (wanita), dan karena mereka (laki-laki) telah menafkahkan sebagian dari harta mereka. ${ }^{1}$

Umumnya orang memahami makna pemimpin di sini sebagai suatu penguasaan dan pengunggulan (laki-laki berkuasa atau lebih unggul dari perempuan), tetapi hakikatnya bukanlah demikian. Hal yang dimaksud adalah kaum laki-laki bekerja dan beraktifitas dalam hidup ini untuk melindungi dan menjaga kaum perempuan, dengan mencari nafkah dan memenuhi segala kebutuhan hidup mereka. Artian kata pemimpin di sini ialah bertanggung jawab dengan mencurahkan segala daya dan upaya demi terpenuhinya segala kebutuhan perempuan (istri) beserta urusan rumah tangga dan anak-anak.

Dalam masalah perekonomian, saat ini di Indonesia tengah dihadapkan pada perekonomian yang semakin pesat, menyebabkan kebutuhan semakin meningakat. Sementara penghasilan laki-laki sebagai ayah, suami dan kepala keluarga sekaligus sebagai pencari nafkah utama dianggap tidak dapat memenuhi setiap kebutuhan. Alhasil mendorong Perempuan

${ }^{1}$ QS. Al-Nisa (4): 34. selaku bagian dari anggota keluarga untuk bekerja mencari penghasilan tambahan guna memenuhi kebutuhan dan meningkatkan perekonomian keluarga. Tidak hanya itu, banyak pula perempuan yang dengan keadaan tertentu memaksakan dirinya menjadi tulang punggung keluarga.

Hukum Islam sendiri memperbolehkan perempuan untuk bekerja mencari nafkah, karena terkadang orang tua atau suami tidak mampu mencukupi dan menanggung biaya hidup mereka. Di sisi lain, adanya faktor latar pendidikan yang minim, membuat perempuan tersebut pada akhirnya mencari pekerjaan yang sesuai dengan kemampuan yang dimilikinya. Seperti, pekerja mini market, pekerja di toko sembako, pekerja pom bensin, atau sebagai pembantu rumah tangga.

Dalam keadaan di mana masih banyaknya perempuan yang belum mampu memaksimalkan potensi untuk mengelola penghasilan agar dapat meningkatkan perekonomian keluarga atau bahkan masih ada perempuan yang masih dalam budaya patriarki. Hal ini tentu saja menjadi daya tarik bagi penulis untuk melakukan penelitian dengan rumusan masalah yang pertama, bagaimana pemberdayaan pekerja perempuan dalam perspektif Hukum Islam? Dan kedua, apakah pemberdayaan pekerja perempuan berdampak pada peningkatan ekonomi keluarga?

\section{LITERATURE REVIEW}

Pembahasan tentang Pemberdayaan Pekerja Perempuan sebagai Upaya Peningkatan Ekonomi Keluarga Perspektif Hukum Islam bukan merupakan suatu hal yang baru dan telah banyak penelitian yang serupa yang membahas masalah ini. Sebagai bahan pertimbangan, penulis menyajikan beberapa penelitian terdahulu sebagai bahan pertimbangan dan perbandingan bagi penulis dalam membuat sebuah karya ilmiah.

Penelitian-penelitian terdahulu diantaranya, pertama, dalam jurnal yang berjudul "Tenaga Kerja Wanita dalam 
Perspektif Islam”. menjelaskan bahwa ada berbagai alasan untuk mendapatkan pembenaran dari masyarakat akan hadirnya perempuan di wilayah publik ini, mulai dari desakan ekonomi keluarga hingga keinginan untuk beraktualisasi sejajar dengan pria. Ditinjau dari norma dan ajaran agama, khususnya agama Islam, sebenarnya tidak ada larangan bagi kaum perempuan untuk bekerja di luar rumah sebagaimana halnya kaum laki-laki. Namun dalam menunaikan hak-haknya tersebut, Islam menganjurkan kaum perempuan untuk tidak melalaikan tugas dan fungsinya dalam keluarga demi terjaga dan terciptanya keluarga yang sakinah, mawadah, warahmah. ${ }^{2}$

Kedua, dalam skripsi yang berjudul "Wanita Karir dalam Perspektif Mahmud Yunus (Studi Kitab Al-Qur'an Al-Karim)". Jenis penelitian ini adalah library research, dengan metodologi penilitian deskriptifanalisis. Memaparkan dan menganalisa data yang bersifat umum mengenai wanita karir terlebih dahulu kemudian menjelaskan pemikiran Mahmud Yunus secara khusus mengenai wanita karir dengan menggunakan pendekatan analisis gender. Di dalamnya menjelaskan bahwa Mahmud Yunus memang tidak membedakan wanita dan pria mengenai kewajibannya karena wanita dan pria merupakan relasi yang serasi. Mahmud Yunus berpandangan bahwa wanita boleh bekerja dan berkarir di luar rumah dengan syarat tetap mampu menjaga kehormatan dan mampu bekerja dan berkakir dengan cara yang terhormat, tanpa mengabaikan norma dan susila yang ada. ${ }^{3}$

Ketiga, dalam Jurnal yang berjudul "Peran Ganda Istri yang Bekerja dalam Membantu Perekonomian Keluarga Buruh Perkebunan Kelapa Sawit pada PT. Bumi

\footnotetext{
${ }^{2}$ Amiroh Ambarwati, "Tenaga Kerja Wanita dalam Perspektif Islam”, Muwazah, Vol. 1, No. 2 (Desember, 2009).

${ }^{3}$ Tatik Fitriyani, "Wanita Karir dalam Perspektif Mahmud Yunus (Studi Kitab Al-Qur'an Al-Karim)", Skripsi (Cirebon: Fakultas Ushuluddin Adab Dakwah 2017).
}

Mas Argo di Kecamatan Sandaran Kabupaten Kutai Timur”. Fokus penelitian ini ialah mendeskripsikan mengenai peran ganda istri yang bekerja di PT. Bumi Mas Argo serta meneliti bagaimana seorang istri mengatur waktu dalam mengurus rumah tangga dan bekerja sebagai buruh. Mengulik peran domestik dan peran publik perempuan dengan metode analisis kualitatif model analisis interaktif. Dengan hasil penelitian yang menunjukan bahwa peran istri dan ibu belum maksimal dalam melaksanakan aktivitasnya di rumah dan tempat kerja. ${ }^{4}$

Dari sekian literatur menunjukan beberapa persamaan yakni, membahas peran ganda perempuan baik secara umum maupun khusus sesuai ajaran agama Islam dan yang menjadi subjeknya hanya perempuan yang telah menikah. Dalam penulisan karya ilmiah ini, penulis tidak hanya membahas perempuan yang telah menikah tetapi juga perempuan yang belum menikah, serta dampaknya terhadap peningkatan ekonomi keluarga yang di dapat dari hasil mereka bekerja di luar rumah. Tentunya dengan norma dan etika yang sesuai dengan hukum Islam dan berbagai dukungan lainnya seperti kebijakan dari tempat kerja dan perlindungan hukum dari negara Indonesia khusunya.

\section{METODOLOGI PENELITIAN}

Metode penelitian merupakan rangkaian cara sistematis yang digunakan oleh peneliti dalam pengumpulan data untuk mengidentifikasi dan menjelaskan berbagai fenomena yang sedang diteliti dan dianalisis. 5 Jenis penelitian yang digunakan adalah penelitian kepustakaan (library research) dan menggunakan jenis penelitian survey, yakni dimaksudkan untuk

\footnotetext{
${ }^{4}$ Risnawati, "Peran Ganda Istri yang Bekerja dalam Membantu Perekonomian Keluarga Buruh Perkebunan Kelapa Sawit pada PT. Bumi Mas Argo di Kecamatan Sandaran Kabupaten Kutai Timur", eJournal Sosiatri-Sosiologi, Vol. 4, No. 13 (2016).

${ }^{5}$ Boedi Abdullah dan Beni Ahmad Saebani, Metode Penelitian Ekonomi Islam (Muamalah) (Bandung: Pustaka Setia, 2014), 20.
} 
mengetahui sesuatu secara keseluruhan dari objek penelitian, dalam hal ini para pekerja perempuan. Penelitian ini bersifat deskriptif kualitatif, yaitu berusaha mengkombinasikan pendekatan nomatif yang dalam hal ini mengacu pada nash alQur'an dan hadits dengan didukung oleh Undang-Undang atau hukum di negara Indonesia yang berhubungan dengan tenaga kerja perempuan, serta pendekatan empiris. ${ }^{6}$

Berdasarkan sumber pengambilannya, data primer yang digunakan adalah bukubuku diantaranya: Faqihuddin Abdul Kodir, dalam buku yang berjudul "60 Hadis HakHak Perempuan dalam Islam: Teks dan Interpretasi”. M. Quraish Shihab, dalam buku yang berjudul "Membumikan AlQur'an". Hadi Dust Muhammadi, "Syakhsyiat-e Zan az-Didgoh-e Islam", penerjemah Alwi Bafaqih, dalam buku yang berjudul "Bukan Wanita Biasa". Wiwik Ambarsari, dalam jurnal yang berjudul "Pemberdayaan Perempuan", Gema Wiralodra, No. 9, Vol. VI. Moh. Rifa'I, Moh. Zuhri, Salomo, dalam "Terjemah Khurlashah Kifayatul Akhyar".

Kedua, data sekunder yang merupakan data pendukung atau data yang diperoleh secara tidak langsung dalam sumbernya. ${ }^{7}$ Data sekunder ini didapatkan dari hasil wawancara dengan 20 (dua puluh) pekerja perempuan yang dijadikan sebagai pendukung terhadap teori yang terkait dengan penelitian ini. Teknik pengumpulan data yang digunakan dalam penelitian ini ialah wawancara. Peneliti akan mengambil beberapa sampel dengan teknik sampling nonprobalitas yang berarti kemungkinan atau peluang setiap anggota populasi untuk menjadi anggota sampel tidak sama dan cara ini bersifat subyektif. Teknik pengambilan sampel yang digunakan adalah jenis purposive sampling, yaitu teknik

${ }^{6}$ Fahmi M. Ahmadi dan Jaenal Arifin, Metode Penelitian Hukum (Jakarta: Lembaga Penelitian UIN Syarif Hidayatullah, 2010), 31.

${ }^{7}$ Iqbal Hasan, Pokok-pokok Materi Metodologi Penelitian dan Aplikasinya (Bogor: Ghalia Indonesia, 2002), 86. pengambilan sampel data dengan pertimbangan tertentu. ${ }^{8}$ Serta dokumentasi berupa rekaman suara dan foto.

\section{KONSEP DASAR}

Pemberdayaan berasal dari kata "daya" yang mendapat awalan ber- menjadi kata "berdaya", artinya memiliki atau mempunyai daya. Daya artinya kekuatan, berdaya artinya memiliki kekuatan. Kata berdaya apabila diberi awalan pe- dan sisipan - $m$ serta akhiran -an menajdi "pemberdayaan" artinya membuat sesuatu menjadi berdaya atau mempunyai daya atau mempunyai kekuatan. ${ }^{9}$

Dalam pengertian "pemberdayaan" mengandung dua kecenderungan. Pertama, yang menekankan kepada proses memberikan atau mengalihkan sebagai kekuasaaan, kekuatan atau kemampuan kepada masyarakat agar individu menjadi lebih berdaya, yang merupakan makna kecenderungan primer. Sedangkan kecenderungan kedua yaitu menekankan pada proses menstimulasi, mendorong atau memotivasi individu agar mempunyai kemampuan atau keberadayaan untuk menentukan apa yang menjadi pilihan hidupnya melalui proses dialog, yang merupakan makna kecenderungan sekunder. Dengan demikian terlihat bahwa pemberdayaan bukanlah proses sepihak melainkan proses dua pihak yang dijalankan untuk kepentingan bersama.

Islam juga memperkuat bahwa kemuliaan ini dibangun di atas realitas kemanusiaan, yang mencakup kaum lakilaki dan perempuan secara setara. Faktor perbedaan tingkat kemuliaan manusia hanya satu yaitu ketaqwaan kepada Allah, maka pahala atau balasan untuk manusia atas segala amal perbuatan tetap sama baik secara kuantitas maupun kualitas.

\footnotetext{
${ }^{8}$ Sugiyono, Memahami Penelitian Kualitatif (Bandung: Alfabeta, 2014), 53-54.

${ }^{9}$ Kamus Besar Bahasa Indonesia, Pusat Pembinaan dan Pengembangan Bahasa, Edisi 2 (Jakarta: Balai Pustaka, 1996), 213-214.
} 
Sebagaimana firman Allah dalam Surah Ali Imran ayat 195:

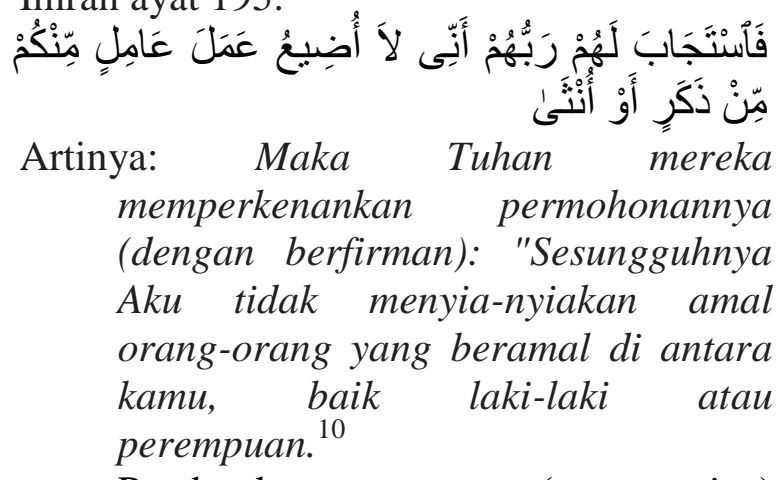

Pemberdayaan

(empowering)

perempuan adalah upaya sistematik untuk memastikan pencapaian kesejahteraan perempuan. Suatu kesejahteraan tidak hanya diukur berdasarkan tingkat kemakmuran material, tetapi lebih terfokus pada upaya memampukan kelompok-kelompok perempuan. Pemberdayaan di sini lebih dititikberatkan pada cara kelompok perempuan mendayagunakan semua potensi yang dimilikinya, cara memelihara lingkup sosial, budaya, ekonomi dan lingkungan, serta cara memahami dan membela hakhaknya sendri. ${ }^{11}$

Islam sangat memperhatikan hak-hak perempuan sebagaimana ia memperhatikan hak-hak laki-laki. Perempuan memiliki hak untuk menyampaikan pikiran; perempuan mempunyai hak untuk memilih, bahkan terdapat masalah-masalah yang menonjol pada perempuan Indonesia lebih baik dari apa yang kita temukan di Negara Barat.

Perempuan memiliki kebebasan dalam aktivitasnya dengan seluruh kehendaknya dan dalam memilih jenis pekerjaan. ${ }^{12}$ Pemberdayaan perempuan harus dimulai dari diri perempuan itu sendiri, dimana pendidikan merupakan faktor kunci sebagai model utama dari pemberdayaan perempuan tersebut. Dalam Islam juga mewajibkan

\footnotetext{
${ }^{10}$ QS. Ali Imran (3): 195.

${ }^{11}$ Siti Musdah Mulia, Muslimah Sejati: Menempuh Jalan Islami Meraih ridha Ilahi (Bandung: Penerbit MARJA, 2011), 252.

${ }^{12}$ Imam Khomeini, Kedudukan Wanita dalam Pandangan Imam Khomaeni, terj. M. Abdul Kadir Alcaff (Jakarta: Lentera, 2004), 86.
}

untuk terus menuntut ilmu pengetahuan, baik ilmu agama maupun ilmu yang lain. Sejak lahir sampai masuk liang lahat, meskipun harus pergi ke tempat yang jauh seperti negeri China. Kewajiban itu berlaku secara sama untuk kaum laki-laki dan kaum perempuan.

Keluarga merupakan unit dasar dalam masyarakat dan merupakan institusi yang paling penting dalam Islam. Dalam keluarga pula, seorang perempuan memiliki peran yang mengikat pada hak dan kewajiban, menghadirkan interaksi antara berbagai generasi yang menyangkut keluarga. ${ }^{13}$ Mengenai posisi perempuan dalam keluarga, Al-Qur'an memberikan hak perempuan sebagai anak, orang dewasa, ibu, istri, anggota masyarakat serta hamba Allah.

Islam telah memerdekakan kaum perempuan dari kungkungan-kungkungan (kezaliman) pada zaman jahiliyah dengan berbagai bentuknya. Dalam islam juga memberikan suatu keuntungan kepada kaum perempuan yang belum pernah ada sebelumnya dalam urusan finansial dan ekonomi. Di satu sisi, Islam memberikan kepada mereka kebebasan dan kemerdekaan penuh dalam hal finansial dan mencegah kekuasaan kaum laki-laki atas harta dan pekerjaan kaum perempuan (istri). ${ }^{14}$ Dalam sebuah riwayat dijelaskan:

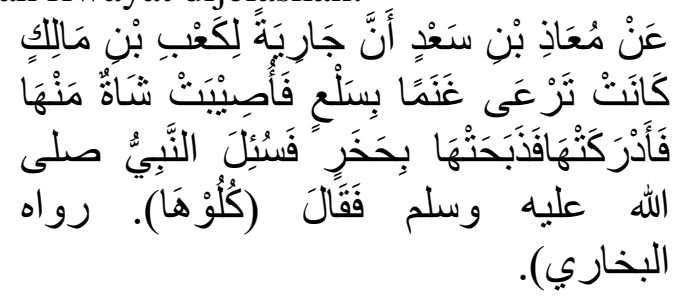

Dari Mu'adz bin Sa'd ra, atau Sa'd bin Mu'adz ra. Ia bercerita bahwa seorang perempuan keluarga Ka'ab bin Malik bekerja mengembala kambing di pegunungan Sala'. Ketika

${ }^{13}$ Barlene May, Wanita Dalam Islam: Kemarin dan Hari Ini, "Hak Asasi Manusia dalam Islam", terj. Badri Yatim, dkk., Cet. 2 (Jakarta: Pustaka Firdaus, 1995), 233.

${ }^{14}$ Yusuf Qardhawi, Fatwa-fatwa Kontemporer, Jilid 3 (Jakarta: Gema Insani Press, 2002), 757. 
terjadi insiden pada salah satu kambingnya, ia bergegas menyembelih-nya. Nabi SAW ditannya tentang hal ini. "Makanlah (kambing itu)”, jawab Nabi SAW. (Shahih Bukhari: 5563).

Hadits ini juga dijadikan dasar oleh Syekh Abu Shuqqa untuk menegaskan bahwa tidak ada larangan sama sekali bagi perempuan untuk bekerja. Hal yang paling fundamental dalam Islam yakni, perempuan sama sekali tidak dihalangi untuk memiliki aktivitas ekonomi yang bisa mendatangkan pendapatan untuk dirinya maupun keluarganya.

Bekerja adalah hak dasar bagi perempuan dalam Islam, maka status dia diberi nafkah tetap tidak menghalangi hak dasar ini. Apalagi pada faktanya, seringkali pendapatan laki-laki juga tidak mencukupi kebutuhan seluruh anggota keluarga. Bahkan tidak sedikit pula keluarga yang tidak memiliki anggota laki-laki yang bisa bekerja untuk memenuhi kebutuhannya. Terlepas dari semua ini, bekerja juga merupakan hak dasar yang tidak bisa dicabut begitu saja ketika masuk dalam lembaga perkawinan. Dalam hal ini, diperlukan adanya negosiasi dan pembagian peran yang bisa diterima oleh kedua belah pihak. ${ }^{15}$

\section{PEMBAHASAN DAN DISKUSI \\ Pemberdayaan Pekerja Perempuan Perspektif Hukum Islam}

Melihat sejarah perempuan beberapa abad kebelakang, kedudukan perempuan pada zaman Nabi Muhammad SAW begitu rendah tidak memiliki martabat dan dapat diperjual-belikan, bahkan kelahiran bayi perempuan dianggap sebagai sebuah bencana. Maka dari itu, al-Qur'an bersikap realistis. Dalam komunitas seperti itu, kebiasaan dan tata cara hidup mereka yang tidak menghargai perempuan tidak mungkin

\footnotetext{
${ }^{15}$ Faqihudin Abdul Kodir, 60 Hadis Hak-hak Perempuan dalam Islam: Teks dan Interpretasi (Yogyakarta: Umah Sinau Mubadalah, 2017), 163165.
}

dapat dikontruksi begitu saja tanda proses transisi secara gradual dan evolitif. ${ }^{16}$

Syafiq Hasyim dalam "Understanding Women In Islam: An Indonesian Perspective", menerangkan:

"Although women are the focus of attention in An-Nisa', problem relating to the discrimination, segregation, and subordination of women are belived to be derived from, and legitimated by, it. For example, in Al-Nisa' (4): $34 . \quad$ In several interpretations of the Qur'an, the word qawwamuna is translated as 'leader'. Such an interpretation leads to a general understanding than men are leader, and that, as superiors, they can not be challenged, even when they are mistaken. This interpretation is then applied to life in more practical terms. Of course, by implication, an interpretation may not always be correct. Although we acknowledge that leadership may be the onus of men, it should be true leadership-just, democratic, and understanding."

Perempuan yang bekerja dan perempuan yang memberi nafkah keluarga adalah buka anominal dalam sejarah Islam. Memang tidak mainstream, tetapi sama sekali tidak dilarang dan tidak bertentangan dengan prinsip-prinsip Islam. Mencari nafkah di bebani kepada laki-laki dalam Islam, karena mereka biasanya yang lebih mudah memperoleh pekerjaan dalam banyak kebudayaan masa dahulu. Mereka juga yang secara fisik lebih memungkinkan untuk bekerja di luar rumah di bandingkan perempuan. Saat ini kesempatan kerja itu terbuka untuk keduanya baik laki-laki dan perempuan. Maka kewajiban nafkah semestinya menjadi tanggung jawab bersama. Lebih tepatnya, menjadi tanggung

${ }^{16}$ Tutik Hamidah, Fiqh Perempuan Berwawasan Keadilan Gender (Malang: UIN-Maliki Press, 2011), 15-29.

${ }^{17}$ Syafiq Hasyim, Understanding Women In Islam: An Indonesian Perspective (Jakarta: Menara Gracia, 2006), 26. 
jawab siapapun yang mampu bekerja dan menghasilkan uang pendapatan. Kewajiban nafkah ini, basisnya bukan pada jenis kelamin, melainkan kemampuan dan kapasitas, sebagaimana kewajibankewajiban yang lain dalam Islam. ${ }^{18}$

Melalui ayat-ayat yang diturunkan alQur'an sejatinya sedang berusaha melakukan transformasi kultural secara arif dan realistik. Dalam kaidah fiqhiyyah, perubahan hukum merupakan suatu keharusan jika kondisi sosiologis mastarakat berubah. Sebuah kaidah tentang perubahan hukum yang dinisbatkan kepada Ibdu Qayyim al-Jauziyyah berbunyi:

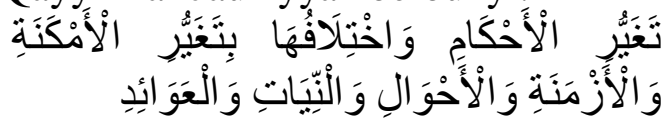

"Perubahan dan perbedaan hukum adalah disebabkan perbedaan tempat, masa, kondisi, motivasi dan budaya."

Lebih lanjut, Ibnu Qayyim alJauziyyah menerangkan bahwa perubahan hukum harus mencapai kemaslahatan manusia, dalam ungkapan yang artinya:

"Syari'ah dibangun atas dasar kebijaksanaan dan kemaslahatan manusia untuk kini dan yang akan datang. Semua hukum-hukum syari'ah adalah adil, rahmat, maslahat dan bijak. Maka setiap persoalan atau kasus hukum yang menyimpang dari dasar-dasar ini, bukanlah bagian dari syari'ah, meskipun diupayakan dengan caracara intelektual". ${ }^{19}$

Adapun dijelaskan oleh Ziba MirHosseini, dalam "Gender Rights and Islamic Law: New Horizons”, yang menerangkan:

"Islamic law - like other system of law - is reactive, in the sense that it reacts to social practices and people's

\footnotetext{
${ }^{18}$ Faqihudin Abdul Kodir, 60 Hadis Hak-hak Perempuan dalam Islam: Teks dan Interpretasi, 170171.

${ }^{19}$ Tutik Hamidah, Fiqh Perempuan Berwawasan Keadilan Gender, 30-31.
}

experiences; it has both the potential and the legal mechanisms to deal with women' demand for equality. We must not forget that most often, legal theory follows practice; that is to say, when social reality changes, than social pressure will effect change in law". ${ }^{20}$

Selain itu, menurut Amina Wadud dalam "Qur'an and Woman: Rereading the Sacred Text from a Woman's Perspective", menerangkan:

"The Qur'an does not attempt to annihilate the defferences between men and women or to erase the significance of functional gender distinction which help every society to run smoothly and fulfil its needs. In fact, compatible mutually supportive functional relationship between men and women can be seen as part of the goal of the Qur'an with regard to society. However, the Qur'an does not propose or support a singular role or single definition of a set of roles, exclusively, for each gender across every culture", 21

Islam sebagai agama yang begitu memuliakan kaum perempuan, mendukung keaktifan seorang perempuan dalam pekerjaan di berbagai bidang. Didukung dengan adanya sejarah keterlibatan perempuan dalam pekerjaan pada masa awal Islam. Hanya saja tidak semua bentuk dan ragam pekerjaan yang terdapat pada masa kini telah ada pada masa Nabi. M. Quraish Shihab dalam buku yang berjudul "Membumikan Al-Qur'an" menjelaskan bahwa mereka boleh bekerja di dalam

${ }^{20}$ Ziba Mir-Hosseini, "Gender Rights and Islamic Law: New Horizons", eds, Islam, Women and the New World: An International Conference Proceedings (Yogyakarta: Center for Women Studies UIN Sunan Kalijaga, 2006), 93.

${ }^{21}$ Amina Wadud, Qur'an and Woman: Rereading the Sacred Text from a Woman's Perspective (New York: Oxford University Press, 1999), 8. 
ataupun di luar rumah, secara mandiri atau bersama orang lain, dengan ketentuan selama pekerjaan tersebut dilakukannya dalam suasana terhormat, sopan, serta selama mereka dapat memelihara agamanya, serta dapat pula menghindari dampakdampak negatif dari pekerjaan tersebut terhadap diri dan lingkungannya.

Tidak semua bentuk dan ragam pekerjaan yang terdapat pada masa kini telah ada pada masa Nabi Muhammad SAW. Kemudia pada akhirnya ulama menyimpulkan bahwa perempuan dapat melakukan pekerjaan apapun selama ia membutuhkan atau pekerjaan itu membutuhkannya dan selama norma-norma agama dan susila tetap terpelihara. ${ }^{22}$

Peranan seorang perempuan sangat diperhatikan dalam pembangunan keluarga. Perempuan yang bekerja di luar rumah secara tidak langsung memiliki peran ganda yaitu di satu sisi dituntut untuk mengabdikan diri terhadap keluarga dalam rumah tangganya, dan di sisi lain perempuan dituntut profesional dalam pekerjaannya di luar rumah. Motivasi perempuan bekerja di luar rumah juga sangat beragam, ada yang sekedar mengisi waktu luang, melanjutkan karier, namun yang utama pada umumnya adalah untuk meningkatkan perekonomian keluarga. Dengan desakan ekonomi keluarga juga makin meluasnya kesempatan kerja yang menyerap tenaga kerja perempuan menjadi faktor yang menguatkan seorang perempuan dalam keluarga memutuskan untuk bekerja di luar rumah.

Dalam Islam, kondisi-kondisi yang dimiliki seorang perempuan dalam rumah tangganya terdapat beberapa hukum bagi para perempuan yang bekerja di luar rumah, Nurul Asmayani dalam "Perempuan Bertanya, Fikih Menjawab" menerangkan:

1. Wajib: Jika harus menanggung hidup dirinya dan keluarganya, kebutuhan masyrakat pada bidang-bidang tertentu,

\footnotetext{
${ }^{22}$ M. Quraish Shihab, Membumikan Al-Qur'an (Bandung: Al-Mizan, 1994), 277-278.
}

serta dapat melaksanakan syaratsyaratnya.

2. Sunnah: Jika untuk membantu suami, ayah/ibu, saudaranya yang miskin untuk memenuhi kebutuhan hidup mereka. mendapat izin dari suami atau orangtuanya dan dapat melaksanakan syarat-syaratnya. $^{23}$

Demikian pula jika penghasilannya (perempuan) tidak terlalu dibutuhkan mengingat orangtua atau suaminya mampu menafkahi dirinya, perempuan diperbolehkan bekerja dengan alasan telah mendapat izin dan ridho dari keluarganya tersebut serta dapat melaksanakan syaratsyaratnya. Adapun hukumnya menjadi haram, jika tidak mendapat izin dari keluarganya dan tidak dapat melaksanakan syarat-syaratnya. Seorang anak wajib berusaha membuat orang tuanya ridha, karena terdapat hubungan sebabmusabab. Berbakti kepada orang tua merupakan sebab, ridha Allah dan ridha orang tua merupakan musabab. Sebagaimana sabda Nabi SAW:

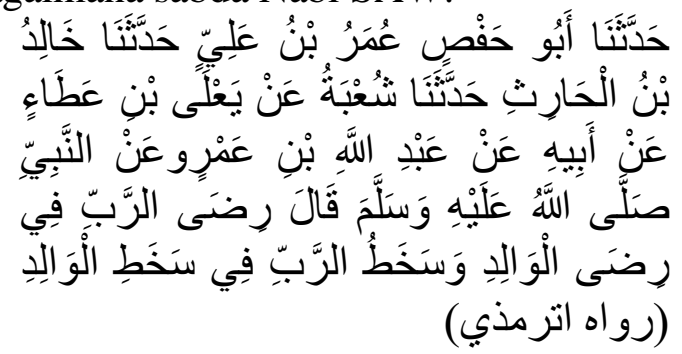

Telah menceritakan kepada kami Abu Hafsh, Umar bin Ali telah menceritakan kepada kami Khalid bin Al Harits telah menceritakan kepada kami telah menceritakan kepada kami Syu'bah dari Ya'la bin Atha' Bapaknya dari Abdullah bin Amr radliallahu 'anhuma dari Nabi shallallaahu 'alaihi wa sallam, beliau bersabda: "Ridha Allah terdapat pada ridha seorang bapak, dan murka Allah juga

${ }^{23}$ Nurul Asmayani, Perempuan Bertanya, Fikih Menjawab, Cet. 2 (Jakarta: PT. Gramedia Pustaka Utama, 2017), 373. 

terdapat pada murkanya seorang
bapak.

Sebagian ulama berpendapat keridhaan orang tua wajib diprioritaskan dibanding dengan melakukan amalan wajib yang hukumnya fardhu kifayah seperti jihad.Hal ini berdasarkan hadits berikut:

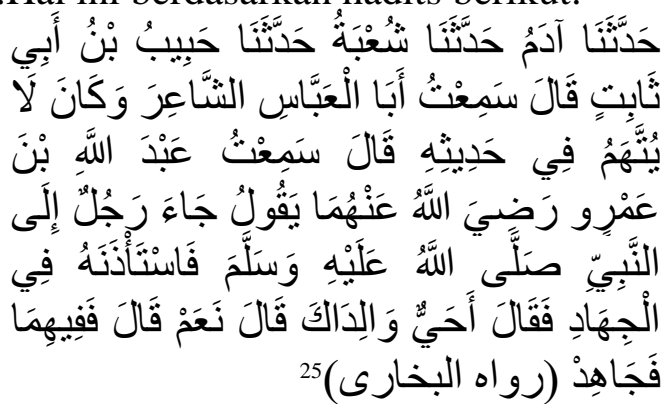

Telah bercerita kepada kami Adam telah bercerita kepada kami Syu'bah telah bercerita kepada kami Habib bin Abi Tsabit berkata aku mendengar Abu Al 'Abbas Asy-Sya'ir, dia adalah orang yang tidak buruk dalam haditshadits yang diriwayatkannya, berkata aku mendengar 'Abdullah bin 'Amru radliallahu 'anhuma berkata: "Datang seorang laki-laki kepada Nabi shallallahu 'alaihi wasallam lalu meminta izin untuk ikut berjihad. Maka Beliau bertanya: "Apakah kedua orang tuamu masih hidup?" Laki-laki itu menjawab: "Iya". Maka Beliau berkata: "Kepada keduanyalah kamu berjihad (berbakti)". ${ }^{26}$

Segala bentuk interaksi yang mampu mendatangkan ridha orang tua tercakup dalam pengertian berbakti kepada kedua orang tua. Mendatangkan keridhaan orang tua dengan cara menaati perintah mereka merupakan salah satu bentuk berbakti. Namun, hal tersebut memiliki batasan selama perintah mereka tidak

\footnotetext{
${ }^{24} \mathrm{Abu}$ Isa Muhammad bin Isa bin Saurah, $A l$ Jami' al-Shahih wa Hua Sunan al-Tirmidzi (Lebanon: Dar Al-kutub Al-Ilmiyah, 1907), 645.

${ }^{25}$ Hāfidz Ahmad ibn Alī ibn hajar al-Asqalān̄̄, Fathu al-Bārī bi SyarhiShahīhu al-Bukhari, jilid 2 (Lebanon: Dar al-Fikr, 1420 H/2000 M), 134.

${ }^{26}$ Az-Zubaidi, Mukhtashar Shahih Bukhari (Bandung: Nuansa Cendekia, 2018), 450.
}

bertentangan dengan perintah Allah. Ridha orang tua merupakan sebab terkabulnya do'a sang anak. Ridha dan murka merupakan sifat Allah SWT. Wajib bagi setiap muslim menetapkan sifat yang ditetapkan Allah bagi diri-Nya sendiri sesuai dengan kesempurnaan dan keagungan Allah.

Sementara itu, Hukum asal perempuan (istri) adalah tinggal di dalam rumah, sebagaimana dalam firman Allah menegaskan:

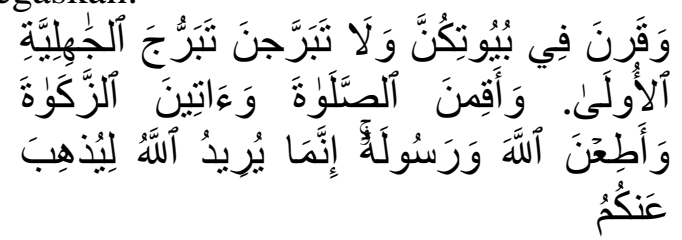

Artinya: Dan hendaklah kamu tetap di rumahmu dan janganlah kamuberhias dan bertingkah laku seperti orang-orang Jahiliyah yang dahulu dan dirikanlah shalat,tunaikanlah zakat dan taatilah Allah dan Rasul-Nya. Sesungguhnya Allah bermaksudhendak menghilangkan dosa dari kamu. ${ }^{27}$

Hal ini tentu tidak berarti istri tidak boleh keluar sama sekali, ia boleh keluar untuk memenuhi keperluan-keperluannya dengan syarat mendapat izin dari suami, aman dari fitnah, dan tidak melanggar syariat. Sebagaimana sabda Nabi Muhamma SAW.

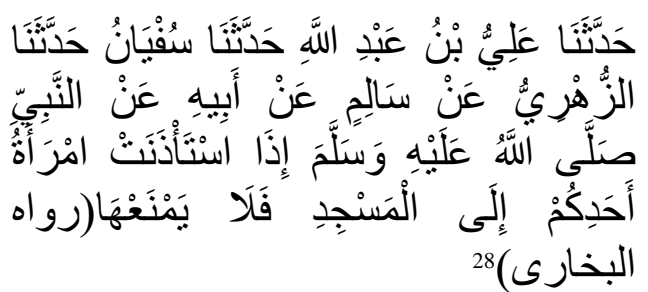

Telah menceritakan kepada kami Ali bin Abdullah Telah menceritakan kepada kami Sufyan Telah menceritakan kepada kami Az Zuhri

\footnotetext{
${ }^{27}$ QS. Al-Ahzab (33): 33.

${ }^{28}$ Imam Sihabudin Ahmad bin Muhammad al-
} Khathib al-Misri, Irsyad al-Sari Ila Shahihil Bukhari, jilid 11 (Lebanon: Dar Al-kutub Al-Ilmiyah, 1996), 524. 
dari Salim dari bapaknya dari Nabi shallallahu 'alaihi wasallam, beliau bersabda: "Jika salah seorang dari isteri kalian meminta izin ke masjid, maka janganlah ia melarangnya". ${ }^{29}$

Al-Hafizh Ibnu Hajar menukil ucapan al-Imam an-Nawawi, "Dari hadits ini diambil dalil bahwa istri tidak boleh keluar dari rumah suaminya kecuali dengan izin suami, karena perintah untuk memberi izin tersebut ditujukan kepada para suami". Jadi, ke mana pun istri pergi, hendaknya dia meminta izin kepada suami. Jika suami tidak memberikan izin, istri tidak boleh memaksakan diri untuk keluar walaupun untuk ibadah. Hanya pada kondisi-kondisi tertentu semisal kondisi darurat yang membahayakan jiwa, seperti kebakaran dalam rumah, ia terpaksa keluar tanpa izin, atau jika ia yakin bahwa suaminya ridha dengan adanya izin yang dahulu atau kebiasaan suami yang memberikan izin. ${ }^{30}$

Mengenai izin seorang istri kepada suami, Syafiq Hasyim dalam "Understanding Women In Islam: An Indonesian Perspective”, menerangkan:

"It is good rule that the members of a family should inform each orther of their activities, but this should not only apply to the wife, but also the husband. A good husband is one who can understand his wife's aspirations and opinions. A good husband who acts according to the rules of good conduct (mu'ashara bi al-ma'ruf), does not enforce his own will. There is no husband in the world who doesn't want his wife to conduct good deeds. The Qur'an says explicitly that a good wife is obedient, protective, and able

\footnotetext{
${ }^{29}$ Imam Az-Zubaidi, Mukhtashar Shahih Bukhari, 620.

${ }^{30}$ M. Nur Ichwan Muslim, Silsilah Faedah Hadits Adab dan Akhlak (2): Ridha Orangtua, dalam https://muslim.or.id/26936-silsilah-faedah-haditsadab-dan-akhlak-2-ridha-orang-tua.html. Diakses pada tanggal 15 Mei 2017.
}

to take care of herself when her husband is away from home. But this kind of wife should also have a good husband, who can perform his obligations". 31

Perempuan tidak dapat merasa aman dan nyaman bekerja di luar rumah tanpa adanya dukungan utama dari keluarganya, kemudian lingkungan sekitarnya, perlindungan dari negaranya, dan kekuatan diri sendiri serta keimaanannya yang diwujudkan dalam niatnya bekerja. Hal yang demikian itu ialah yang kemudian disebut sebagai pemberdayaan. Untuk mendukung teori-teori tersebut, terdapat 20 responden yang telah diwawancari.

Secara keseluruhan, narasumber telah memiliki izin dan dukungan yang cukup baik keluarga, lingkungan dan tempat kerja. Mereka mampu menjaga etika dan moral sesuai ajaran agama Islam. Bagi pekerja perempuan yang statusnya sebagai seorang anak, pada intinya mereka ingin belajar mandiri dan tidak lagi mengandalkan pemberian dari orangtua, tetapi justru ingin membahagiakan orangtua. Sementara bagi pekerja perempaun yang statusnya sebagai seorang istri, pada intinya mereka ingin membantu untuk menambah penghasilan dan dapat memenuhi kebutuhan yang amat banyak. Hal tersebut juga efektif untuk ikut di andalkan untuk memenuhi kebutuhan ekonomi keluarga, tidak hanya mengandalkan dari satu sumber saja yakni penghasilan suami. Bagi pekerja perempuan yang statusnya sebagai seorang janda, dengan keadaan yang mewajibkan mereka untuk bekerja menjadikan mereka perempuan yang kuat, tangguh dan tidak mengharap pemberian dari oranglain.

Dalam kitab Kifayatul Akhyar menerangkan tentang kewajiban memberi nafkah kepada orang tua dengan 2 syarat berikut:

1. Orang tua yang miskin,

${ }^{31}$ Syafiq Hasyim, Understanding Women In Islam: An Indonesian Perspective, 158. 
2. Orang tua yang tidak sehat akalnya. Sedangkan kewajiban memberi nafkah kepada anak dengan syarat berikut:

1. Fakir,

2. Kanak-kanak,

3. Miskin karena musibah,

4. Miskin karena tidak sehat akalnya. Kewajiban anak memberi nafkah kepada orang tua dengan syarat berikut:

1. Anak dalam kelonggaran rezeki, yaitu mempunyai makanan yang cukup untuk dimakan dalam waktu itu,

2. Orang tua tidak mempunyai harta sedikit pun. Kalau orang tua mempunyai harta, anak tidak wajib memberi nafkah meskipun orang tua dalam keadaan sakit.

Sedangkan seorang anak yang miskin tetapi mempunyai pekerjaan, sebagian ulama berpendapat orang tua tidak wajib memberi nafkah. Tapi ulama yang lain berpendapat wajib memberi nafkah. Pendapat yang kedua menurut penulis kitab ini ialah yang paling kuat, karena kalau anak mempunayi harta tetapi tidak di tangan, maka orang tua wajib memberi nafkah, nanti ketika harta tersebut sudah di tangan, pemberian orang tua wajib di kembalikan. ${ }^{32}$

Pada umumnya, pekerja peremuan yang statusnya sebagai anak, bekerja dengan alasan mencari pengalaman, membantu orangtua, dan yang utama bisa memenuhi kebutuhan dan keinginan diri sendiri. Para perempuan yang telah menikah memutuskan untuk bekerja di luar rumah dengan alasan dan kondisi dimana belum mempunyai anak, sehingga banyak waktu yang bisa di lakukan untuk memperbanyak penghasilan dan mempersiapkan kebutuhan saat hamil dan melahirkan. Selain itu, ada orangtua yang membantu mengasuh anaknya saat perempuan tersebut bekerja di luar rumah, bahkan dalam wawancara, terdapat pekerja yang tidak bisa memberi ASI, sehingga ia

\footnotetext{
${ }^{32}$ Moh. Rifa'i, et al., Terjemah Khulashah Kifayatul Akhyar (Semarang: CV. Toha Putra, 2011), 342-345.
}

merasa harus bekerja untuk bisa membeli susu pengganti ASI.

Adapula kondisi dimana suami bekerja namun upahnya diberi setiap satu bulan sekali dan seringkali tidak cukup untuk memenuhi kebutuhan harian. Alhasil seorang istri bekerja diluar rumah untuk memperoleh upah dan bisa memenuhi kebutuhan harian tersebut, disamping mereka tidak memiliki modal untuk membuka usaha mandiri di rumah. Saat ini kesemua pekerja perempuan yang di wawancarai, belum ada yang memiliki usaha mandiri dan kreatif di rumah. Mereka fokus dengan pekerjaan yang mereka lakukan saat ini sebagai pewagai atau karyawan. Walau begitu, bukan berarti mereka tidak memiliki tujuan lain, banyak dari mereka yang saat ini menabung agar bisa membuka usaha mandiri di rumah.

\section{Dampak Pemberdayaan Pekerja Perempuan terhadap Peningkatan Ekonomi Keluarga}

Terkait perekonomian keluarga, saat ini perempuan juga ikut berperan serta dalam menghasilkan pendapatan untuk keluarga. Pendapatan yang diperoleh oleh seorang perempuan yang bekerja di ranah publik tidak akan begitu berarti jika hanya sekedar untuk memenuhi kebutuhan sehari-hari. Tetapi juga diperlukan pengeloaan yang baik terhadap pendapatan tersebut agar tercapai yang namanya peningkatan ekonomi keluarga. Guna mengetahui apakah dengan pemberdayaan pekerja perempuan saat ini, perempuan mampu meningkatkan perekonomian keluarganya. Dari penghasilan yang diterima oleh pekerja perempuan, terdapat beberapa perubahan terhadap perekonomian keluarga, yakni sebagai berikut:

1. 9 (sembilan) pekerja perempuan (anak) yang semula bergantung pada pemberian orangtua atau anggota keluarga lain semisal kakaknya, dengan pemberian uang saku kurang lebih Rp 10.000,sampai Rp 15.000,- per hari atau mereka hanya meminta ketika ada sesuatu yang 
ingin dibeli. Setelah mereka bekerja, mereka memperoleh penghasilan kurang lebih Rp 700.000,- sampai yang memperoleh UMK Rp 1.750.000,sebagaimana telah tercantum pada bab sebelumnya. Dengan mereka bekerja dan memiliki penghasilan sendiri, tentu membuat penghasilan orangtua dapat di alokasikan untuk kebutuhan yang lainnya, mengingat mereka tidak lagi meminta dan mendapat uang dari orangtua, justru mereka bisa memberi kepada orangtua.

2. Dua pekerja perempuan (istri), jika mereka tidak bekerja, maka untuk memenuhi kebutuhan keluarga hanya ditopang oleh satu orang saja, yakni suami dengan penghasilan yang semula kurang lebih ada yang Rp1.200.000,sampai dengan Rp 2.400.000,- per hari, maka dengan istri bekerja keluarga memiliki tambahan untuk memenuhi kebutuhan tiap bulan dengan gaji istri yang kurang lebih Rp 1.300.000,- sampai Rp 1.750.000,-. Jika di total, penghasilan keluarga per bulan kurang lebih sebanyak Rp 3.000.000,- per bulan.

3. 4 (empat) pekerja perempuan (ibu), jika mereka tidak bekerja maka keluarga hanya memperoleh pemasukan dari suami kurang lebih ada yang $\mathrm{Rp}$ 500.000,- sampai dengan Rp 2.000.000,per bulan. Dengan istri ikut bekerja yang memperoleh gaji bulanan kurang lebih ada yang Rp 1.300.000,- sampai Rp 1.750.000,- per bulan, maka penghasilan keluarga bertambah kurang lebih ada yang memperoleh $\mathrm{Rp} 2.250 .000$,- sampai Rp 3.750.000,- per bulan

4. 3(tiga) pekerja perempuan (ibu) yang memperoleh gaji/upah kurang lebih $\mathrm{Rp}$ 900.000,- sampai Rp2.400.000,- per bulan jika ditotal dengan penghasilan suami kurang lebih ada yang Rp 2.400.000,- sampai Rp 3.000.000,- per bulan, maka penghasilan keluarga mencapai kurang lebih Rp 3.000.000,sampai Rp 5.000.000,- per bulan. Jumlah ini adalah perkiraan peneliti karena tidak semua dari pekerja perempuan memperoleh upah bulanan, dan tidak semua dari suami mereka memperoleh penghasilan yang tetap dan dapat dipastikan jumlahnya tiap bulan.

5. 2 (dua) pekerja perempuan (janda), memperoleh upah ada yang Rp 24.000,per hari ada pula yang memperoleh $\mathrm{Rp}$ 2.700.000,- per bulan. Dalam hal ini tidak terjadi peningkatan secara signifikan terhadap perekonomian keluarga, karena mereka yang menjadi pencari nafkah utama dan satu-satunya untuk kebutuhan diri sendiri dan/atau yang menjadi tanggungannya. ${ }^{33}$

Dengan cara mengelola keuangan keluarga yang dilakukan oleh masingmasing pekerja perempuan memiliki dampak positif terhadap perekonomian keluarga, yakni dengan perempuan bekerja setelah menyelesaikan pekerjaannya mereka memperoleh upah dan dapat dimanfaatkan untuk memenuhi kebutuhan. Namun tingkat kesejahteraan-nya berbeda-beda.

1. Bagi pekerja perempuan yang mampu mengelola keuangan dengan baik, dalam arti cukup untuk segala kebutuhan pokok dan dapat menyisihkan untuk menabung dan modal usaha mandiri, dapat dikatakan telah meningkatkan perekonomian keluarga. Mereka tidak hanya sekedar memberi sumbangsih untuk kebutuhan sehari-hari, tetapi mereka mampu mengelola dan memiliki tabungan masa depan. Selain dapat meningkatkan perekonomian keluarga, pekerja perempuan semacam ini juga memperoleh kehormatan yang lebih dari sekedar bergantung kepada anggota keluarga lainnya.

2. Sementara bagi pekerja perempuan menggunakan pendapatannya hanya untuk kebutuhan pokok, tidak terlalu signifikan dalam peningkatan ekonomi keluarga. Namun, hal itu dapat

\footnotetext{
${ }^{33}$ Hasil wawancara pada pekerja perempuan pada tanggal 27 April - 3 Mei 2018.
} 
dipengaruhi oleh beberapa hal diantaranya, upah yang didapat terlalu kecil, sehingga terkadang lebih besar kebuthan daripada pendapatan yang diterima, faktor lain adanya rasa kurang percaya diri untuk melakukan hal yang lebih dari sekedar menjadi buruh/pekerja. Hal ini akan menyebabkan jika mereka berhenti bekerja sebagai buruh/pekerja, tidak ada lagi pendapatan yang diterima dan tidak dapat memenuhi kebutuhan, mengingat mereka tidak memiliki tabungan atau usaha mandiri. ${ }^{34}$

Adapun menurut penulis, perempuan boleh bekerja dengan beberapa ketentuan yang telah dijelaskan. Sesuai dengan pengalaman para narasumber sebagai pekerja perempuan, terdapat berbagai dampak baik positif dan negatif yang terjadi pada pekerja perempuan. Namun, banyak dari mereka yang belum menyadari bahwa tidak akan selamanya menjadi bawahan orang lain. Menjadi karyawan tentunya memiliki batas waktu, usia, dan kontrak. Sementara perekonomian akan terus meningkat, sehingga perlu adanya kreativitas dan pengelolaan yang cerdas terhadap ekonomi rumah tangga.

\section{KESIMPULAN}

Berdasarkan hasil penelitian tentang pemberdayaan pekerja perempuan sebagai upaya peningkatan ekonomi keluarga perspektif hukum Islam, peneliti menarik kesimpulan, yakni pertama, dalam hal pemberdayaan pekerja perempuan sebagai upaya meningkatkan perekonomian keluarga, hampir semua pekerja perempuan sesuai dengan pandangan hukum Islam. Mereka tidak bekerja semena-mena tanpa adanya komunikasi yang baik dengan anggota keluarga yang lain, dukungan dari lingkungan sekitar, serta tetap menjaga etika dan moral dalam pekerjaan mereka. sementara terdapat pekerja yang merasa kurang mendapat dukungan dari lingkungan

\footnotetext{
${ }^{34}$ Hasil wawancara pada pekerja perempuan pada tanggal 27 April - 3 Mei 2018.
}

sekitar yang masih menganut budaya patriarki, tetapi ia mampu bertahan, memiliki prinsip tersendiri yaitu bahwa saat ini mencari pekerjaan tidaklah mudah, jadi ketika seseorang mendapat pekerjaan yang baik dan hasilnya bisa untuk mencukupi kebutuhan, maka pekerjaan tersebut tidak boleh disia-siakan.

Simpulan yang kedua, pemberdayaan pekerja perempuan memiliki dampak positif terhadap peningkatan ekonomi keluarga, yakni penghasilan keluarga meningkat. Walaupun peningkatannya berbeda, yaitu tingkat rendah dan tingkat tinggi. Penghasilan yang digunakan untuk sekedar memenuhi kebutuhan sehari-hari, maka berada dalam tingkat rendah. Sedangkan pekerja perempuan yang penghasilannya dikelola dengan baik seperti menabung dan dijadikan modal untuk membuka usaha tambahan, termasuk dalam peningkatan ekonomi yang tinggi. Seperti yang dilakukan oleh beberapa pekerja perempuan, dimana mereka mengalokasikan penghasilan untuk modal membuka usaha mandiri di rumah (toko sembako atau toko pakaian), sehingga selain kebutuhan keluarga saat ini dapat terpenuhi, juga untuk kebutuhan masa depan.

\section{DAFTAR PUSTAKA}

Abdullah, Boedi dan Beni Ahmad Saebani. Metode Penelitian Ekonomi Islam (Muamalah). Bandung: Pustaka Setia, 2014

Ahmadi, Fahmi M. dan Jaenal Arifin. Metode Penelitian Hukum. Jakarta: Lembaga Penelitian UIN Syarif Hidayatullah, 2010.

Al-Asqalān̄i,Hāfidz Ahmad ibn Alī ibn hajar. Fath al-Bārī bi SyarhiShahīhu al-Bukhari, jilid 2. Lebanon: Dar alFikr, 1420 H/2000 M.

Al-Misri, Imam Sihabudin Ahmad bin Muhammad al-Khathib. Irsyad al-Sari Ila Shahihil Bukhari, jilid 11. Lebanon: Dar Al-kutub Al-Ilmiyah, 1996. 
Ambarwati, Amiroh. "Tenaga Kerja Wanita dalam Perspektif Islam", Muwazah, Vol. 1, No. 2 (Desember, 2009).

Asmayani, Nurul. Perempuan Bertanya, Fikih Menjawab, Cet. 2. Jakarta: PT. Gramedia Pustaka Utama, 2017.

Az-Zubaidi. Mukhtashar Shahih Bukhari. Bandung: Nuansa Cendekia, 2018.

Departemen Agama RI. Al-Qur'an dan Terjemahnya. Bandung: Sinar Baru Algensindo, 2010.

Fitriyani, Tatik. "Wanita Karir dalam Perspektif Mahmud Yunus (Studi Kitab Al-Qur'an Al-Karim)", Skripsi. Cirebon: Fakultas Ushuluddin Adab Dakwah 2017.

Hamidah, Tutik. Fiqh Perempuan Berwawasan Keadilan Gender. Malang: UIN-Maliki Press, 2011.

Hasan, Iqbal. Pokok-pokok Materi Metodologi Penelitian dan Aplikasinya. Bogor: Ghalia Indonesia, 2002.

Hasyim, Syafiq. Understanding Women In Islam: An Indonesian Perspective. Jakarta: Menara Gracia, 2006.

Ibn Saurah, Abu Isa Muhammad bin Isa. AlJami' al-Shahih wa Hua Sunan alTirmidzi. Lebanon: Dar Al-kutub AlIlmiyah, 1907.

Kamus Besar Bahasa Indonesia. Pusat Pembinaan dan Pengembangan Bahasa, Edisi 2. Jakarta: Balai Pustaka, 1996.

Khomeini, Imam. Kedudukan Wanita dalam Pandangan Imam Khomaeni, terj. M. Abdul Kadir Alcaff. Jakarta: Lentera, 2004.

Kodir, Faqihudin Abdul. 60 Hadis Hak-hak Perempuan dalam Islam: Teks dan Interpretasi. Yogyakarta: Umah Sinau Mubadalah, 2017.

May, Barlene. Wanita Dalam Islam: Kemarin dan Hari Ini, "Hak Asasi Manusia dalam Islam", terj. Badri Yatim, dkk., Cet. 2. Jakarta: Pustaka Firdaus, 1995.

Mir-Hosseini, Ziba. "Gender Rights and Islamic Law: New Horizons", eds,
Islam, Women and the New World: An International Conference Proceedings. Yogyakarta: Center for Women Studies UIN Sunan Kalijaga, 2006.

Mulia, Siti Musdah. Muslimah Sejati: Menempuh Jalan Islami Meraih ridha Ilahi. Bandung: Penerbit MARJA, 2011.

Muslim, M. Nur Ichwan Muslim, Silsilah Faedah Hadits Adab dan Akhlak (2): Ridha Orangtua, dalam https://muslim.or.id/26936-silsilahfaedah-hadits-adab-dan-akhlak-2ridha-orang-tua.html. Diakses pada tanggal 15 Mei 2017.

Rifa'i, Moh. et al. Terjemah Khulashah Kifayatul Akhyar. Semarang: CV. Toha Putra, 2011.

Risnawati. "Peran Ganda Istri yang Bekerja dalam Membantu Perekonomian Keluarga Buruh Perkebunan Kelapa Sawit pada PT. Bumi Mas Argo di Kecamatan Sandaran Kabupaten Kutai Timur", eJournal Sosiatri-Sosiologi, Vol. 4, No. 13 (2016).

Shihab, M. Quraish. Membumikan AlQur'an. Bandung: Al-Mizan, 1994.

Sugiyono. Memahami Penelitian Kualitatif. Bandung: Alfabeta, 2014.

Wadud, Amina. Qur'an and Woman: Rereading the Sacred Text from a Woman's Perspective. New York: Oxford University Press, 1999.

Yusuf Qardhawi, Fatwa-fatwa Kontemporer, Jilid 3. Jakarta: Gema Insani Press, 2002. 